
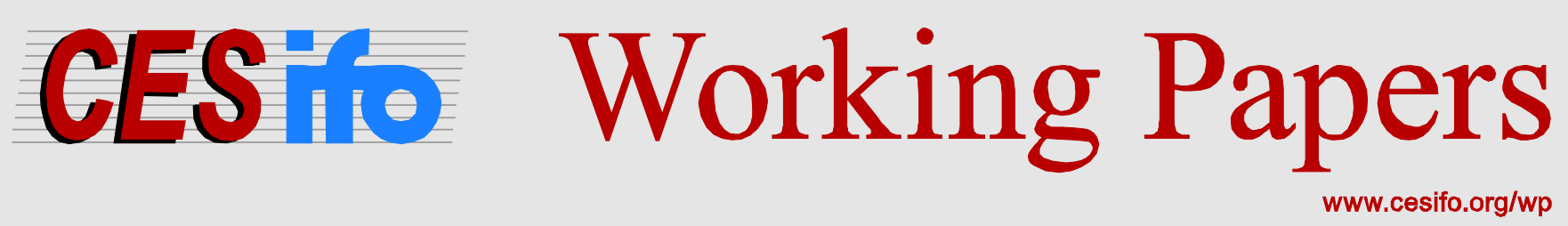

\title{
Vertical Integration and Valuation of International Oil Companies
}

\author{
Bård Misund \\ Petter Osmundsen \\ Marius Sikveland
}

\begin{abstract}
CESIFO WORKING PAPER NO. 5061
CATEGORY 9: RESOURCE AND ENVIRONMENT ECONOMICS

NOVEMBER 2014
\end{abstract}

An electronic version of the paper may be downloaded

- from the SSRN website:

- from the RePEc website:

- from the CESifo website:

www.SSRN.com

www.RePEc.org

www.CESifo-group.org/wp

\section{CESifo}




\title{
Vertical Integration and Valuation of International Oil Companies
}

\begin{abstract}
This paper studies financial statement information from the 50 largest international oil and gas companies during 1992 to 2011 and evaluates their relation to market values. In particular, we examine how this relationship is affected by accounting method choice (successful efforts versus full cost accounting) and vertical integration. We find that net income is more value relevant for full cost companies compared to companies that use the successful efforts accounting method. Furthermore, the value relevance of oil and gas reserves is different among successful efforts and full cost companies. Larger reserves among successful efforts companies are awarded a premium by stock markets. The value relevance of book value is significantly lower for integrated companies than for pure upstream companies. We also find that the value relevance of oil and gas reserves is different for upstream and integrated companies.
\end{abstract}

JEL-Code: F230, G000, L710, M410.

Keywords: company valuation, value-relevance, financial analysis, oil and gas industry.

Bård Misund*

The University of Stavanger Business School

Norway - 4036 Stavanger

bard.misund@uis.no

Petter Osmundsen

Department of Industrial Economics

Faculty of Science and Technology

University of Stavanger / Norway

Petter.Osmundsen@uis.no
Marius Sikveland

University of Stavanger

Business School

Norway - 4036 Stavanger

marius.sikveland@uis.no

*corresponding author 


\section{Introduction}

The accounting scandals of the beginning of this Millennium highlight the potential failures of GAAP and financial disclosures (Penman, 2003). This paper studies the value relevance of accounting measures in the international petroleum industry. In particular, we investigate how the value relevance is affected by accounting method choice and vertical integration. Our results should be of interest to oil companies, financial analysts, investors and financial accounting standard setters.

The accounting literature advocates that an important characteristic of financial statements, and in particular earnings (net income), is the usefulness for predicting future cash flows (see e.g. Lev, 1989). However, there is some uncertainty regarding the relevance of historical cost accounting for predicting future cash flows in the oil and gas industry (FASB, 1982). This doubt is based upon the notion that upstream oil and gas exploration and production operations embody certain characteristics that distinguish them from other operations involving asset acquisition and use (Wright \& Gallun, 2005). These characteristics have resulted in different accounting practises among oil and gas companies (see FASB 1982). Oil and gas companies are allowed to choose between two competing accounting methods for capitalization and amortization of exploration and production expenses. While the successful efforts (SE) method requires oil companies to capitalize only costs incurred from exploration of successful oil and gas wells, under the alternative full cost (FC) method, all costs related to exploration must be capitalized. It can be argued that the existence of two competing accounting methods may reduce the quality and value-relevance of accounting information.

Measurement errors may also arise because of use of the unit-of-production method of amortizing oil and gas assets, and the existence of two competing methods for accounting for mergers and acquisitions. ${ }^{1}$

We extend the studies by Quirin et al. (2000) and Cormier and Magnan (2002) by examining the effect of accounting method choice and company characteristics such as vertical integration, on the value relevance of the accounting measures. We apply a value relevance methodology based on the Ohlson (1995) residual income valuation model to contrast the value-relevance of performance measures. Using a dataset of the 50 largest international oil and gas companies over the period 1992-2011, we examine the relative value-relevance of oil company accounting numbers and examine the effect of vertical integration.

We examine both integrated and upstream international oil and gas companies, thus augmenting previous studies that have mainly concentrated on US companies whose primary business involves exploration, development and production (E\&P) of oil and gas (e.g. Quirin et al., 2000; Berry \& Wright, 2001; Bryant 2003). Few academic studies have been carried out on valuation of integrated international oil companies, and they do not address accounting information (e.g. Osmundsen et al., 2006; 2007). Our sample of international integrated and upstream companies allows us to compare the value relevance of these two types of companies.

Studies of the value-relevance of accounting information from US E\&P companies typically use a large number of companies for periods of 2-4 years (e.g. Quirin et al., 2000; Berry \& Wright, 2001; Bryant 2003). By contrast, our data set (1992-2011), allows us to investigate market and company behaviour over 19 years, covering a least one full oil price cycle. This enables us to take advantage of additional information in the timeseries dimension. Our data set covers a period of substantial industry restructuring during the late 1990s and early 2000s, which few studies have examined.

The remainder of the paper is organized as follows. In the next section we provide an overview of the literature. In Section 3 we describe the research design, econometric specification and hypothesis development. Section 4 describes the data and in Section 5 we present and discuss the result. In the last section we conclude our findings.

\section{Literature review}

An important aspect of financial statements, in particular earnings, is to assist users of the financial statements in predicting future cash flows (Lev, 1989), thus facilitating equity valuation analysis. This view presupposes that the relationship between market valuation and accounting earnings is a measure of the usefulness of earnings (i.e. earnings quality). ${ }^{4}$ Moreover, the FASB Statement of Financial Accounting Concepts No.1. states that:

The primary focus of financial reporting is information about an enterprise's performance provided by measures of earnings and its components. Investors, creditors, and others who are 
concerned with assessing the prospects for enterprise net cash inflows are especially interested in that information. Their interest in an enterprise's future cash flows leads primarily to an interest in information about its earnings... (FASB 1978).

Furthermore:

Information about enterprise earnings and its components measured by accrual accounting generally provides a better indication of enterprise performance than does information about current cash receipts and payments. (FASB, 1978)

According to results from prior studies earnings are more value-relevant than operating cash flow (Dechow 1994, Biddle, Seow, \& Siegel 1995; Rayburn 1986; Sloan 1996). In her seminal paper, Dechow (1994) predicts that under the following circumstances, cash flows are predicted to suffer more from timing and matching problems that reduce their ability to reflect company performance: i) the shorter the performance measurement interval, ii) the greater the volatility of the company's working capital requirements and investment and financing activities, and iii) the longer the company's operating cycle. Her results from empirical tests are consistent with her predictions.

The view that earnings are more value-relevant than operating cash flow has recently been contested by others who claim that the earnings quality has decreased in recent years (Francis \& Schipper 1999; Bradshaw \& Sloan 2002, Hodge 2003). Moreover, the literature suggests that the higher value-relevance of earnings compared to cash flow might vary with industry affiliation (see e.g. Biddle et al., 1995; Aharony, Falk \& Yehuda, 2003). In fact, the extant literature has suggested that this is the case for the oil and gas industry. For instance, the valuerelevance of earnings has been found to be lower than cash flows in the oil and gas industry (Quirin et al. 2000; Cormier \& Magnan, 2002). This indicates that industry-specific value-relevance studies can provide important insights into the relation between accounting figures and market value of equity (MVE).

In the oil and gas industry, the conventional view is that historical cost accounting may be inappropriate for accurately conveying the oil and gas companies' financial performance to the financial markets, as demonstrated by the following statement by the Financial Accounting Standards Board (FASB):

"An important quality of information that is useful in making rational investment, credit, and similar decisions is its predictive value-specifically, its usefulness in assessing the amounts, timing, and uncertainty of prospective net cash inflows to the enterprise. Historical cost based financial statements for oil and gas producing enterprises have limited predictive value. Their usefulness is further reduced because a uniform accounting method is not required to be used for costs incurred in oil and gas producing activities." (FASB, 1982).

There are several reasons for the lack of confidence in historical cost accounting in the oil and gas industry. According to Wright \& Gallun (2005), upstream oil and gas exploration and production operations embody certain characteristics that distinguish them from other operations involving asset acquisition and use; characteristics which are frequently cited as the primary factors responsible for the development of different accounting practises in the oil and gas industry:

1. Risks are high and often there is a low probability of discovering commercial reserves.

2. There is often a long time lag between acquiring permits and licenses and the ultimate production of reserves.

3. There is not necessarily any correlation between expenditures and results.

4. The underlying value of the reserves (which represent the major economic worth of a company) cannot be valued reliably enough to be recorded on the balance sheet.

5. The discovery of new reserves, which cannot be valued reliably enough to be recorded as income, is a major future income-earning event.

6. High costs and risks often result in joint operations.

The existence of multiple methods for accounting for oil and gas assets may further confuse investors. Companies, whose primary business is exploration, development and production of oil and gas assets, can choose between two accounting methods; the FC and the SE method. Under the FC method all costs incurred from exploration activities are capitalized and subsequently amortized according to the unit-of-production depreciation method. The SE method, on the other hand, allows only costs incurred from successful exploration activities to be capitalized, and subsequently amortized according to the unit-of-production depreciation method. 
The SE method will potentially result in lower initial net income, and higher future net income, compared to the full cost method. The SE method is accordingly perceived as a more conservative accounting method than the FC method, although this is not straightforward (see e.g. Al-Jabr \& Spear, 2004). The two accounting methods lead to different values for net income and book equity, making it difficult for users of accounting information to determine the financial performance of oil and gas companies.

In an attempt to compensate for the confusion caused by the existence of competing accounting methods, oil and gas companies are required to disclose additional information related to their exploration and production activities (FASB, 1982). These supplementary oil and gas disclosures include both accounting and operational (e.g. production and reserves) information. Most empirical studies on the relation between oil companies' accounting figures and their market value focus on the value-relevance of information disclosed in the supplementary oil and gas disclosures. One strand of literature examines the value-relevance of successful efforts vs. full cost methods (see e.g. Bryant, 2003; Bandyopadhyay, 1994). The empirical evidence does not support any single accounting method, however. Other studies investigate the value-relevance of amounts of proven reserves and the discounted future cash flows of these reserves (the standardized measure), see e.g. Harris \& Ohlson, 1987; Boone, 2002. While the earlier studies struggled to provide evidence for the valuerelevance of the standardized measure, Boone (2002) exploits advances in recent accounting theory and empirical analysis, and provides evidence that the standardized measure is in fact value-relevant.

Other accounting methods such as the unit-of-production depreciation method and the pooling-of-accounts method for accounting ofmergers may also result in measurement errors that may affect the reliability of accounting figures. Under the unit-of-production method, oil and gas assets are amortized using the ratio of production of oil and gas to the balance of total reserves at the beginning of the year (calculated as the year-end balance minus the current year's production). The idea is that the cost of exploration and development is matched with the revenues from production. However, this method typically results in oil and gas investments being too rapidly depreciated, resulting in so-called legacy assets (Antill \& Arnott, 2002). Legacy assets are oil and gas assets that still produce cash flows, but are absent from the balance sheets.

The existence of two separate methods for accounting for mergers may further exacerbate valuation uncertainty through reduced earnings quality (FASB 1999). Prior to 2001, merging companies could choose to account for a merger using either the pooling-of-interest method or the purchase method. Unlike the purchase method, the pooling method does not require companies to record the premium paid for the transaction, nor report the acquired assets at fair market value. Consequently, pooling companies avoid increased future amortization and depreciation, which affect future earnings. The existences of two methods for accounting of merger transactions may result in investors having lower reliance in accruals than in cash flows. Empirical studies provide evidence that choice of method for accounting for mergers influences the value-relevance of accounting data (see e.g. Christian \& Jones, 2004). This result bears relevance for our study due to the substantial industry restructuring in the oil industry during 1998-2002 (Weston, 2002; Weston, Johnson \& Siu, 1999). Merging oil and gas companies used both methods.

\section{Research design, econometric specification and hypothesis development}

\section{The value-relevance of accounting information: the benchmark model}

Following Ball \& Brown’s (1968) and Beaver's (1968) seminal works on the topic, researchers have tried to determine the relationship between accounting figures and valuation using statistical methods. However, until Feltham and Ohlson's revitalization of the Residual Income Valuation model, RIV (Ohlson, 1995, 1999; Feltham \& Ohlson, 1995, 1996), the research framework lacked a formal theoretical model linking accounting figures to valuation. This model enabled a better understanding of how accounting information formally could be linked to valuation. By linking market value closer to the fundamentals, i.e. earnings and book value of equity, this method has instigated a considerable amount of capital markets research (see e.g. Kothari, 2001).

Based on the dividend discount model, Ohlson (1995) develops a model that describes how market value is related to abnormal earnings, book value, and other information. ${ }^{5}$ This can be written as:

$$
M V E_{t}=B V_{t}+\alpha_{1} N I_{t}^{a}+\alpha_{2} v_{t},
$$


where $M V E$ is the market value of equity, $B V$ is the book value of equity, $N I^{a}$ is abnormal earnings and $v$ is a vector of other value relevant information. According to Ohlson (1995), other information represents "valuerelevant events that have yet to have an impact on the financial statements." In the Ohlson-based valuerelevance literature, equation (1) is commonly operationalized by estimating the equation:

$$
M V E_{i t}=\alpha_{0}+\beta_{1} B V_{i t}+\beta_{2} N I_{i t}+\beta_{3} v_{i t}+\varepsilon_{i t},
$$

where $v$ represents proxies for other information. In this literature, net income is commonly used as a proxy for abnormal income. Proxies for other information are sometimes included, other times ignored. A relevant example from the literature is Bryant (2003). She uses book equity, net income and a measure of the net present value of oil and gas reserves (proxy for other information) as her primary explanatory variables. However, since recent evidence has indicated that the amount of proven oil and gas reserves is more value-relevant than the values of reserves (Berry, Wilcox and Wright, 2004), we use the former measure. The resulting econometric model is estimated as follows: ${ }^{7}$

$$
M V E_{i t}=\alpha_{0}+\beta_{1} B V_{i t}+\beta_{2} N I_{i t}+\beta_{3} R_{i t}+\varepsilon_{i t}
$$

where $R$ is the natural logarithm total proven oil and gas reserves (million barrels of oil equivalents), and $\varepsilon$ is the error term. Model (3) represents our benchmark model, which will be tested against alternative value-relevance models.

The impact of company circumstances on the value relevance of performance measures

The value relevance of performance measures may be affected by certain characteristics of the oil and gas industry or company circumstances. An important example is the choice of accounting method for oil and gas exploration activities, i.e. the choice between the full cost and the successful efforts methods. Another example is vertical integration. The oil industry consists of both pure upstream companies and integrated companies. In our analysis, we examine both the effect of accounting method choice and the extent of vertical integration on the value relevance of three performance measures. In the following we will describe the econometric approaches, and also consider how the company circumstances may potentially impact on the value relevance of the three performance measures.

\section{Part I. Effects of accounting method choice}

Accounting method choice could impact the value relevance of some of the performance measures. For instance, using either the SE or FC methods will result in different values for earnings and book equity (see e.g. Bryant, 2003). Under the SE method, completed costs of successful exploratory wells, completed costs of development wells, and completed costs of production equipment and facilities are capitalized and are subject to DD\&A. Expenses incurred from the drilling of dry wells (oil and gas wells deemed not economically viable) are expensed directly in the income statement. The capitalized costs are amortized according to the unit-ofproduction depreciation method using the following formula (UoP):

$$
U o P=\frac{C C_{t}}{O G R_{t-1}^{E}} \times P_{t}
$$

where, $C C$ (capitalized costs) is the book value of proven reserves at end of a period, $O G R^{E}$ is the estimated reserves at beginning of a period - calculated as the reserves at the end of the period less the production for the period - and $P$ is the production for the period. According to Antill and Arnott (2002) the unit-of-production method may result in a too rapid amortization of book value of reserves, resulting in so-called legacy assets.

Under the FC method, all exploration expenses incurred from drilling activity (dry wells and economic viable wells) are capitalized, and amortized according to the unit-of-production method or the unit-of-revenue method (see e.g. Wright and Gallun, 2005). Under both methods, capitalized costs are included in the balance sheet item property, plant and equipment (PP\&E), and the amortization included in the DD\&A in the income statement. In 
addition, both the capitalized costs and the amortization of the capitalized costs are disclosed separately in the supplementary oil and gas disclosure (see e.g. SFAS No 69: FASB, 1982).

The topic of which method is optimal has been debated over the last 30 years. The supporters of FC argue that FC reflects how oil companies search for, acquire, and develop reserves. Another argument that is commonly used is that FC results in smaller fluctuations in earnings than SE. The underlying argument is the assumption that the users of financial statements are primarily interested in earnings and changes in earnings from one period to the next (see e.g. Wright and Gallun, 2005). This may be the reason why FC is used by small and medium sized oil companies. The large and integrated companies, on the other hand hold large portfolios of petroleum assets and the expensing of dry wells, for instance, will have a smaller effect on earnings and earnings variability than for smaller companies. The most important argument against FC is that it allows the capitalization of costs incurred from the drilling of unsuccessful wells, thus creating assets on the balance sheet that will not generate future cash flows. Hence, they do not meet the definition of an asset. Furthermore, it can be argued that assessing the efficiency in finding and developing oil fields of FC companies is more difficult than for SE companies, because this information is not revealed in the former's balance sheets.

This topic was also debated between the FASB and the SEC during the late 1970s and early 1980s. First, the Statement of Financial Accounting Standards No. 19, (SFAS No. 19: FASB, 1977), required oil and gas companies to account for their oil and gas activities at historical cost using successful efforts method (SE) instead of the full cost method (FC). However, the SEC (Accounting Series Releases No. 253) proposed that oil companies should be permitted to use either of the SE and FC methods (SEC, 1978). Finally, the FASB issued Statement of Financial Accounting Standards (SFAS) No. 69, which to this day determines the information content of SEC filings and financial reports (FASB, 1982).

We examine the effect of accounting method choice by using the dummy variable technique. This entails multiplying the explanatory variables in equation (3) with the dummy variable FC. In the following model, FC is equal to 1 for full cost companies and 0 for SE companies:

$$
\begin{aligned}
M V E_{i t} & =\alpha_{0}+\alpha_{1} F C+\beta_{1} B V_{i t}+\beta_{2} B V_{i t} \times F C+\beta_{3} N I_{i t}+\beta_{4} N I_{i t} \times F C \\
& +\beta_{5} R_{i t}+\beta_{6} R_{i t} \times F C+\varepsilon_{i t}
\end{aligned}
$$

The models for the two types of companies become

$$
\begin{aligned}
& M V E_{i t}=\alpha_{0}+\beta_{1} B V_{i t}+\beta_{3} N I_{i t}+\beta_{5} R_{i t}+\varepsilon_{i t} \\
& \text { (SE companies) } \\
& M V E_{i t}=\left(\alpha_{0}+\alpha_{1}\right)+\left(\beta_{1}+\beta_{2}\right) B V_{i t}+\left(\beta_{3}+\beta_{4}\right) N I_{i t} \\
& +\left(\beta_{5}+\beta_{6}\right) R_{i t t}+\varepsilon_{i t}
\end{aligned}
$$

This method allows us to separate the effects of accounting method choice on the value relevance of accounting variables. For instance, the slope coefficient on net income is $\beta_{3}$ for SE companies and the sum of $\beta_{3}$ and $\beta_{4}$ for FC companies. If $\beta_{4}$ is statistically significant then this indicates that FC and SE companies' coefficients on profitability are different from each other.

The null hypothesis is that the accounting method has no effect on the value relevance of the accounting variables. If the coefficients on the interaction terms $\left(\alpha_{1}, \beta_{2}, \beta_{4}, \beta_{6}\right)$ are significantly different from 0 the null is rejected. The formal statement of the research hypothesis, in alternative form, is:

$\mathrm{H}_{1}$ : The value relevance of the performance measures are affected by accounting method choice

\section{Part II: Effects of company characteristics: vertical integration}

Our data sample consists of both integrated companies and pure upstream oil and gas producers (the independent exploration and production companies, the E\&Ps). While the integrated companies span a large part of the value chain, from upstream (exploration and crude oil production) to downstream (refinery and chemicals), the pure E\&Ps are concentrated upstream. For the latter companies, the choice between SE and FC 
methods may represent the largest source of measurement errors in the accounting numbers. The integrated companies, consisting of a more diverse mix of assets, may be subject to other additional sources of measurement errors. First, very few integrated companies use the FC method. Most use the SE method. Second, downstream assets are capitalized and amortized according to a different set of accounting methods and rules. The accounting numbers reported by integrated oil and gas companies may therefore be more difficult for analysts to interpret and hence poor predictors of future cash flows. Third, the major integrated companies have been involved in a major industry restructuring during 1998-2002. Prior studies have indicated that periods of industry restructuring can result in reduced value relevance of earnings compared to cash flows (Christian and Jones, 2004; Misund et al., 2008).

To capture the difference between upstream and integrated companies, we include a dummy variable, INT, in our model. The dummy variable INT is 1 for integrated companies and 0 for upstream companies. The resulting model is represented as:

$$
\begin{aligned}
M V E_{i t} & =\alpha_{0}+\alpha_{1} I N T+\beta_{1} B V_{i t}+\beta_{2} B V_{i t} \times I N T+\beta_{3} N I_{i t}+\beta_{4} N I_{i t} \times I N T \\
& +\beta_{5} R_{i t}+\beta_{6} R_{i t} \times I N T+\varepsilon_{t}
\end{aligned}
$$

The models for the two types of companies become

$$
\begin{array}{rlr}
M V E_{i t} & =\alpha_{0}+\beta_{1} B V_{i t}+\beta_{3} N I_{i t}+\beta_{5} R_{i t}+\varepsilon_{i t} & \text { (upstream companies) } \\
M V E_{i t} & =\left(\alpha_{0}+\alpha_{1}\right)+\left(\beta_{1}+\beta_{2}\right) B V_{i t}+\left(\beta_{3}+\beta_{4}\right) N I_{i t} & \\
& +\left(\beta_{5}+\beta_{6}\right) R_{i t}+\varepsilon_{i t} & \text { (integrated companies) }
\end{array}
$$

If the coefficients on the interaction terms are statistically significant, this indicates a different value relevance of the performance measures among integrated and upstream E\&Ps.

The null hypothesis is that the coefficients on accounting variables reported by upstream and integrated oil and gas companies are the same. If the coefficients on the interaction terms $\left(\alpha_{1}, \beta_{2}, \beta_{4}, \beta_{6}\right)$ are significantly different from 0 , the null is rejected.

The third research hypothesis, also stated in alternative form is:

$\mathrm{H}_{2}$ : The extent of vertical integration affects the value relevance of accounting figures.

\section{Sample data}

The sample consists of 50 of the largest oil and gas companies for the years 1992-2011. Accounting data and the amounts of proven oil and gas reserves were collected from the IHS Herold database. ${ }^{8}$ The IHS Herold database consists of financial and operating data from annual financial statements of publicly traded energy companies worldwide. As a measure of market value we use market capitalization as at year-end. Market value of equity, accounting figures and book equity are all scaled by the previous year's year-end market value of equity. As a measure of other information we use the natural logarithm of the amount of oil and gas reserves (log of millions of barrels of oil equivalent, BOE). Our data set includes a total of 747 firm-years. Descriptive statistics for the variables in our models are reported in Table 1. 
Table 1

Descriptive Statistics of Sample Data 1992-2011 pooled $^{9}$

\begin{tabular}{lccccc}
\hline Variable & No. Obs. & Mean & $\begin{array}{c}\text { Standard } \\
\text { deviation }\end{array}$ & Min & Max \\
\hline MVE (USD) & 747 & 38873 & 67373 & 38 & 504240 \\
BV (USD) & 747 & 18078 & 28891 & -249 & 181494 \\
NI (USD) & 747 & 3315 & 6164 & -5805 & 46867 \\
R (boe) & 747 & 4006 & 5738 & 7 & 24932 \\
\hline
\end{tabular}

Variable definitions are as follows: MVE is the market value of equity as measured as at year-end. NI is year-end earnings after taxes and minorities, year-end and BV is year-end book value of equity (total shareholders' equity). $\mathrm{R}$ is the year-end total proven reserves of oil and gas, measured in million barrels of oil equivalent (boe).

Our study differs from similar studies in that our sample consists of international oil and gas companies, and both integrated and upstream companies. To the best of our knowledge, no previous study has been conducted on the effect of vertical integration on the value relevance of oil companies' financial information. The IHS Herold database identifies which companies are integrated and which are E\&P companies. We use this division in our econometric analysis.

\section{Results and discussion}

Our analysis is carried out in two parts. First, we examine the impact of accounting method choice on the value relevance of accounting variables. In the second part we investigate the impact of vertical integration on the relationship between performance measures and market valuation of oil companies.

\section{Part I. Effects of accounting method choice}

In this section we examine how accounting method choice affects the value relevance of accounting figures.

Table 2 provides the results of the econometric analysis. The significant coefficient of the interaction term $\mathrm{NI} \times \mathrm{FC}$ indicates that the value relevance of accounting figures is affected by the choice of accounting method. $\mathrm{H}_{1}$ is not rejected. There is an ongoing discussion in the academic literature about which of the two competing accounting methods - FC or SE - is the optimal approach to account for oil and gas exploration. Early studies obtained results in favour of the SE method (Harris and Ohlson, 1987, Bandyopadhyay, 1994). However, more recent studies have found that net income and book equity calculated under the FC method were more value relevant than accounting variables calculated under the SE method (Bryant, 2003). The empirical evidence on the accounting methods is, therefore, mixed. While Bryant's sample consists of US upstream oil and gas companies from 1994-1996, our study consists of international, and both E\&P and integrated companies, from 1992-2011. Our sample is more recent and may therefore reflect the current relationship between accounting figures and market values.

The results also indicate that the value relevance of oil and gas reserves is different between SE and FC companies. The coefficients on the interaction term on reserves and Full Cost (RxFC) are significant at the 10percent level and negative, indicating that larger reserves among SE companies are awarded a premium by stock markets. An explanation, related to vertical integration, is presented in the next section. While upstream companies use either the FC or the SE accounting method, most integrated oil and gas companies apply the SE method. Hence, the negative coefficients on oil and gas reserves may be an effect of size. Osmundsen et al. (2006) found that size is positively correlated to market value in integrated oil companies. 
Table 2

The value-relevance of accounting figures in the oil and gas industry: the effect of accounting method choice

\begin{tabular}{lccc}
\hline & Coefficient & $\begin{array}{c}\text { Pooled } \\
\text { regression }\end{array}$ & $\begin{array}{c}\text { Random } \\
\text { effects }\end{array}$ \\
\hline Constant & $\alpha_{0}$ & $1.053^{* * *}$ & $1.116^{* * *}$ \\
& & $(6.36)$ & $(5.30)$ \\
FC & $\alpha_{1}$ & 0.917 & 0.803 \\
& & $(1.56)$ & $(1.2)$ \\
NI & $\beta_{3}$ & -1.079 & -0.91 \\
& & $(-1.09)$ & $(-0.98)$ \\
NI x FC & $\beta_{4}$ & $2.334 * *$ & $2.177^{* *}$ \\
& & $(2.33)$ & $(2.30)$ \\
BV & $\beta_{1}$ & $0.627 * *$ & $0.747 * * *$ \\
& & $(2.38)$ & $(2.76)$ \\
BV x FC & $\beta_{2}$ & -0.066 & -0.135 \\
& & $(-0.23)$ & $(-0.45)$ \\
R & $\beta_{5}$ & -0.019 & -0.037 \\
& & $(-1.21)$ & $(-1.63)$ \\
R x FC & $\beta_{6}$ & $-0.138 *$ & -0.123 \\
& & $(-1.81)$ & $(-1.37)$ \\
N & & 747 & 747 \\
R ${ }^{2}$-adj & & 0.27 & 0.26
\end{tabular}

$*$ = significant at the $10 \%$ significance level, $* *=$ significant at the $5 \%$ significance level, $* * *=$ significant at the $1 \%$ significance level, $\mathrm{t}$ values in parenthesis. Variable definitions are as follows: MVE is the market value of equity as measured as at year-end scaled by the previous year's year end market value. $\mathrm{X}$ represents net income or the other accounting variables (except book equity). NI is earnings after taxes and minorities, and BV is year-end book value of equity (total shareholders' equity). R is the natural logarithm of the year-end total reserves of oil and gas, as reported to SEC.

Part II: Effects of company characteristics: vertical integration

This part of the analysis examines the effect of vertical integration on the value relevance of accounting measures, using a sample of both upstream and integrated oil and gas companies. While upstream assets consist mainly of capitalized costs from exploration and development of oil and gas reserves, the downstream assets consist of pipelines, refineries and chemicals plants. The latter assets are capitalized and depreciated according to a different set of accounting methods and rules than the upstream assets. Hence, integrated companies encompass a more diverse mix of assets and apply a larger set of accounting and depreciation methods. A priori, one might expect that the financial figures of integrated companies would be more complicated for the financial analysts and investors to interpret.

As Table 3 shows, the coefficient on the interaction term (BVxINT) is significant and negative. The value relevance of book value is significantly lower for integrated companies than for pure E\&Ps. The fact that integrated companies possess a complex asset structure generating earnings may provide an explanation. Book value is perhaps more difficult to use in the estimation of market value of these companies. The results from the pooled regression indicate that the value relevance of oil and gas reserves is different among E\&P and integrated companies. The coefficient on the interaction term (RxINT) is significant and positive, indicating that larger reserves among integrated companies are awarded by a premium by stock markets. However, this is not supported by the random effects model. 
Table 3

The value-relevance of accounting figures in the oil and gas industry: the effect of vertical integration

\begin{tabular}{|c|c|c|c|}
\hline & & $\begin{array}{l}\text { Pooled } \\
\text { regression }\end{array}$ & $\begin{array}{l}\text { Random } \\
\text { effects }\end{array}$ \\
\hline Intersect & \multirow[t]{2}{*}{$\alpha_{0}$} & $1.728 * * *$ & $1.636 * *$ \\
\hline Upstream & & (2.95) & (2.08) \\
\hline Intersect & \multirow[t]{2}{*}{$\alpha_{1}$} & -0.747 & -0.724 \\
\hline INT & & $(-1.23)$ & $(-0.91)$ \\
\hline \multirow[t]{2}{*}{ NI } & \multirow{2}{*}{$\beta_{3}$} & $1.115^{* * *}$ & $1.117 * * *$ \\
\hline & & (3.75) & (4.13) \\
\hline \multirow[t]{2}{*}{ NI x INT } & \multirow[t]{2}{*}{$\beta_{4}$} & -0.687 & -0.768 \\
\hline & & $(-1.1)$ & $(-1.26)$ \\
\hline \multirow[t]{2}{*}{ BV } & \multirow[t]{2}{*}{$\beta_{1}$} & $1.017 * * *$ & $1.145^{* * *}$ \\
\hline & & (3.38) & (3.32) \\
\hline$B V x$ & \multirow[t]{2}{*}{$\beta_{2}$} & $-0.711^{* *}$ & $-0.734 * *$ \\
\hline INT & & $(-2.29)$ & $(-2.06)$ \\
\hline \multirow[t]{2}{*}{$\mathrm{R}$} & \multirow[t]{2}{*}{$\beta_{5}$} & $-0.163^{* *}$ & -0.159 \\
\hline & & $(-2.16)$ & $(-1.61)$ \\
\hline \multirow[t]{2}{*}{ R x INT } & \multirow[t]{2}{*}{$\beta_{6}$} & $0.1554 * *$ & 0.151 \\
\hline & & (2.02) & (1.51) \\
\hline $\mathrm{N}$ & & 747 & 747 \\
\hline $\mathrm{R}^{2}$ & & 0.293 & 0.291 \\
\hline
\end{tabular}

* = significant at the $10 \%$ significance level, ** = significant at the $5 \%$ significance level, $* * *=$ significant at the $1 \%$ significance level, $\mathrm{t}$ values in parenthesis. Variable definitions are as follows: MVE is the market value of equity as measured as at year-end scaled by the previous year's year end market value. X represents net income. NI is earnings after taxes and minorities and BV is year-end book value of equity (total shareholders' equity). $\mathrm{R}$ is the natural logarithm of the year-end total reserves of oil and gas, as reported to SEC.

\section{Conclusion}

The objective of this study is to determine the value-relevance of accounting figures in the oil and gas sector. The conventional view among financial standard setters is that historical cost accounting is inadequate for valuation in the oil and gas industry. For instance, accounting methods may result in measurement errors. Furthermore, the existence of competing accounting methods results in different values for earnings and book equity. Moreover, the value relevance of performance measures may be affected by firm circumstances, such as extent of vertical integration.

Using accounting and operational information from 50 of the largest international oil and gas companies during 1992-2011, we investigate the value-relevance of accounting figures. In particular, we examine the effect of accounting method choice (SE vs. FC) and vertical integration on the value relevance of performance measures in the oil and gas industry.

We find that net income is more value relevant for full cost companies than for companies that use the successful efforts accounting method. The value relevance of oil and gas reserves is different among SE and FC companies. Larger reserves among SE companies are awarded a premium by stock markets. We also find that the value relevance of book value is significantly lower for integrated companies than for pure E\&Ps. The fact that integrated companies possess a complex asset structure generating earnings may provide an explanation, and investors may find it more difficult to use book values to estimate the value of these companies. The value relevance of oil and gas reserves is also different among E\&P and integrated companies.

In our analyses we have applied SEC reserves. There is a discrepancy between the approaches of SPE (Society of Petroleum Engineers) and SEC regarding the booking of oil and gas reserves. Oil companies typically possess both proven reserves and probable reserves. The SEC requires oil companies to report only proven reserves, thus disregarding the importance of probable reserves. Value relevance of the two resource classifications is an important topic for future research. 


\section{Notes}

1. The two competing methods for accounting for mergers are he purchase and the pooling-of-interests methods. See e.g. Christian \& Jones (2004).

2. For general analyses of valuation multiples, see Damodaran (2002), and Liu, Nissim \& Thomas (2001).

3. Enterprise value (EV) is calculated as the sum of the market value of debt and the market value of equity. In practice, however, EV is calculated as the sum of the market value of equity and the book value of interest bearing debt.

4. See e.g. Schipper \& Vincent (2003) for a discussion on the concept of earnings quality.

5. This relation holds under the assumptions of the clean surplus property and certain time-series properties (see Ohlson, 1995).

6. As heteroscedasticity typically results in inefficient OLS estimators, we scale the explanatory variables with the previous year's market value of equity (Easton and Sommers, 2003). The standard errors are adjusted for any remaining heteroscedasticity or autocorrelation in the disturbances, use clustered robust standard errors. See e.g. Akbar \& Stark (2003) for a discussion on scale and scale effects in market-based accounting research.

7. Founded in 1948, IHS Herold. is an independent research company that specialises in the analysis of companies, transactions and trends in the global energy industry (http://www.herold.com/).

8. We have carried out an examination of correlations among explanatory variables. The results indicate that correlations are not high enough to cause concerns regarding multicollinearity. 


\section{References}

Aharony, J., Falk, H., Yehuda, N., 2003. Corporate Life Cycle and the Value-relevance of Cash Flow Versus Accrual Financial Information (Working Paper, Bolzano School of Economics and Management).

Akbar, S., Stark, A.W. 2003. Discussion of scale and the scale effect in market-based accounting research. Journal of Business Finance and Accounting 30 (1\&2), 57-72.

Al-Jabr, Y., Spear, N., 2004. Accounting Method Choice and Accounting Conservatism in the Oil and Gas Industry (Working paper, University of Melbourne).

Antill, N., Arnott, R., 2002. Oil Company Crisis, Managing Structure, Profitability and Growth. Oxford Institute for Energy Studies, Oxford.

Ball, R., Brown, P., 1968. An empirical evaluation of accounting income numbers. Journal of accounting Research 6, 159-178.

Bandyopadhyay, S.P., 1994. Market reactions to earnings announcements of successful efforts and full cost firms in the oil and gas industry. The Accounting Review 69(4), 657-674.

Beaver, W. H., 1968. The information content of annual earnings announcements. Journal of Accounting Research, 67-92.

Berry, K.T., Wright, C.J., 2001. Disclosures: an assessment of the market’s perception of firms' effort and ability to discover reserves. Journal of Business Finance and Accounting 28, 741-769.

Berry, K.T., Wilcox, W., Wright, C., 2004. The relative information content of the components of the reserve disclosures: reserve quanitites vs. the standardized measure. International Journal of Accounting, Auditing and Performance Evaluation, 1 (3), 267-287.

Biddle, G.C., Seow, G.S., Siegel, A., 1995. Relative versus incremental information content. contemporary accounting research $12,1-23$.

Boone J.P., 2002. Revisiting the reportedly weak value-relevance of oil and gas asset present values: The roles of measurement error, model misspecification, and time period idiosyncrasy. The Accounting Review 77, 73-106.

Bradshaw, M., Sloan, R., 2002. GAAP versus the Street: an empirical assessment of two alternative definitions of earnings. Journal of Accounting Research, 41-66.

Bryant, L. 2003. Relative value-relevance of the Successful Efforts and Full Cost Accounting methods in the oil and gas industry. Review of Accounting Studies 8, 5-28.

Christian, C., Jones, J.P., 2004. The value-relevance of earnings and operating cash flows during mergers. Managerial Finance 30 (11), 16-28.

Cormier, D., Magnan, M. 2002. Performance reporting by oil and gas firms: contractual and value implications. Journal of International Accounting, Auditing and Taxation 11, 131-153.

Damodaran, A., 2002. Investment Valuation. New York, Wiley Finance.

Dechow, P., 1994. Accounting earnings and cash flows as measures of firm performance: the tole of accounting accruals. Journal of Accounting and Economics 17: pp. 3-42.

Feltham, G.A., Ohlson, J.A., 1995. Valuation and clean surplus accounting for operating and financial activities. Contemporary Accounting Research 11, 689-731.

Feltham, G.A., Ohlson, J.A., 1996. Uncertainty resolution and the theory of depreciation measurement. Journal of Accounting Research 11, 668-731.

Financial Accounting Standards Board, 1977. Statement of financial accounting standards no. 19: Financial Accounting and Reporting by Oil and Gas Producing Companies. Stamford, FASB.

Financial Accounting Standards Board, 1978. Statement of Financial Accounting Concepts No.1: Objectives of Financial Reporting by Business Enterprises. Stamford, FASB.

Financial Accounting Standards Board, 1982. Statement of financial accounting standards no. 69: Disclosures about oil and gas producing activities. Stamford, FASB.

Financial Accounting Standards Board, 1999. Exposure Draft: Proposed Statement of Financial Accounting Standards - Business Combinations and Intangible Assets. Stamford,: FASB.

Francis, J., Schipper, K., 1999. Have financial statements lost their relevance? Journal of Accounting Research 37(2), 319-352.

Harris, T., Ohlson, J.A., 1987. Accounting disclosures and the market's valuation of oil and gas properties. The Accounting Review 62, 651-670.

Hodge, F., 2003. Investors' perceptions of earnings quality, auditor independence, and the usefulness of audited financial information. Accounting Horizons 17 (Supplement), 37-48.

Kothari, S.P., 2001. Capital markets research in accounting. Journal of Accounting and Economics 31, 105-231.

Lev, B., 1989. On the usefulness of earnings and earnings research: lessons and directions from two decades of empirical research. Journal of Accounting Research (Supplement), 153-192.

Liu, J., Nissim, D., Thomas, J., 2001. Equity valuation using multiples. Journal of Accounting Research 40, 135-171. 
Misund, B., Asche, F. and P. Osmundsen. 2008. Industry upheaval and valuation: Empirical evidence from the international oil and gas industry. The International Journal of Accounting 43, 398-424.

Ohlson, J.A., 1995. Earnings, book values, and dividends in equity valuation. Contemporary Accounting Research 11, 661-687.

Ohlson J.A., 1999. Positive (zero) NPV projects and the behavior of residual earnings. Journal of Business Finance and Accounting 30, 7-16

Osmundsen, P., Asche, F., Misund, B., Mohn, K., 2006. Valuation of international oil companies. Energy Journal 27(3), 49-64.

Osmundsen, P., Mohn, K, Misund, B., Asche, F., 2007. Is oil supply choked by financial market pressures? Energy Policy 35, 1, 467-474.

Penman, S.H., 2003. The quality of financial statements: perspectives from the recent stock market bubble. Accounting Horizons 17 (Supplement), 77-96.

Quirin, J. J., Berry, K.T., O’Bryan, D., 2001. A fundamental analysis approach to oil and gas firm valuation. Journal of Business Finance and Accounting 27 (7), 785-820.

Rayburn, J., 1986. The association of operating cash flow and accruals with security returns. Journal of Accounting Research 24, 112-137.

Schipper, K., Vincent, L., 2003. Earnings quality. Accounting Horizons 17 (Supplement), 97-110.

Sloan, R.G., 1996. Do stock prices fully reflect information in accruals and cash flows about future earnings? The Accounting Review 71, 289-315.

UBS Warburg, 2003. Global Integrated Oil Analyzer, quarterly assessment of the strategies and valuation of the world's largest integrated oil companies.

U.S. Securities and Exchange Commission (SEC), 1978. Accounting Series Release No 253. Washington, D.C.: SEC.

Vuong, Q.H., 1989. Likelihood ratio tests for model selection and non-nested hypotheses, Econometrica 57, 307-333.

Weston, J.F., 2002. The Exxon-Mobil merger: an archetype. Journal of Applied Finance 12, 69-82.

Weston, J.F., Johnson, B.A., Siu, J.A., 1999. Mergers and restructuring in the world oil industry. Journal of Energy Finance and Development 4, 149-183.

Wright, CJ, Gallun, R.A., 2005. International Petroleum Accounting. Tulsa, Oklahoma, PennWell. 